\title{
Surgery in a Rural Private Charitable Hospital - An Early Experience
}

\author{
Md. Mustafizur Rahman Khan' ${ }^{1}$, M A Mannan ${ }^{2}$, M A Matin ${ }^{3}$, Khandaker Ejaz Ahmed". \\ Rowshan Ara Begum 5
}

\begin{abstract}
:
A retrospective study was carried out in Sahera Hasan Memorial Hospital, Garpara, Manikganj, from July 2001 to Jume 2005 to assess the safety of surgery in a remote nural setting, and to present an andit of the nature and outcome of the surgery and their complications. A total of 3.431 patients were seen in ottpatient and 613 different operations were done during the period. Most common operation was open cholecystectomy $(42.41 \%)$ followed by herniormaphy $(13.70 \%)$, excision of benign skin and subcutanteous lesions $(13.38 \%)$ and appendicectony $(12.23 \%)$. Most of the surgeries were elective $(85.48 \%)$. General anaesthesia was given in $51.88 \%$ cases. Overall complications in open cholecystectony, appendicectomy and hemirrhaphy were $6.21 \%$. Only no major biliary complications $(0.77 \%)$ were observed. Skin and soft tisste infection (SSI) rate in open cholecystectomy, appendiceotmy and herniorrhaphy were $1.92 \%, 2.38 \%$ and $5.33 \%$ respectively. No mortality was observed. Overall data suggest that surgical care can be given satisfactorily in rural setting with satisfactory results provided appropriate facilities and relevant expertise can be made available.
\end{abstract}

\section{Introduction:}

Surgical health care in Bangladesh is mostly provided by government health facilities and it is limited mostly to urban areas. The services available are not adequate to address the vast majority of rural people. With the purpose of providing health care services to the rural people Sahera Hasan Memorial Hospital (SHMH) was established in a village (Gaupara) of Manikganj district in July 2001.

1. Associate Professor, Department of Surgery. Holy Family Red Crescent Medical College and Hospital (HFRCMC\&H). Dhaka.

2. Associate Professor and Head of the Department of Anaesthesiology. HFRCMC\&I, Dhaka.

3. Assistant Professor, Department of Anaestlesiology, HFRCMC\&H, Dhakil.

4. Junior Consultan, Department of Anaesthesiology. HFRCMC\&H, Dhaki.

5. Professor and Head of the Department of Gynaecolgy and Obstetrics, HFRCMC\&H, Dhaka.
Minimum charge for all the services are taken to meet the maintenance cost of the hospital. Almost all the basic facilities for modern surgery are provided in the hospital. Two fulltime medical officers are appointed to provide daily out patient services and to cover emergencies. Patients unmanageable at the hospital are referred to the district hospital. On the first and third Friday the surgery specialist and on the second and fourth Friday Gynaecology and Obstetrics specialist advise the patients. Thus there are two days in a month for specialized surgical care. There is no facility for daily emergency surgical services but emergency cases admitted the day before or on the day of the scheduled surgery are operated.

Almost all the surgeries are attended by a specialist visiting anesthesiologist. A single surgeon and often guest surgeons do the 
surgery. The surgeons also provide outpatient consultation on the scheduled day. The aim of this study was to assess the safety of surgery in a remote rural setting, and to present an audit of nature and outcome of the surgery and their complications.

\section{Materials and method:}

Data were collected retrospectively from the database maintained in Shahera Hasan Memorial Hospital, Garpara, Manikganj. The study period was July 2001 to June 2006. Patients for surgery were selected from those seen at the outpatient by the consultant and also by medical officers. All the patients were assessed for surgical fitness by consultant anesthesiologist. A guideline for surgical fitness was maintained. Patients with ASA grade I and II were selected. Patients with predicted high risk were not selected for operation. A few high-risk operations were done as the patients were very poor and gave consent for high-risk surgery. An experienced anaesthesiologist, except those done under local anaesthesia, attended all the operations. Pulse oximeter was available to monitor the patients during anaesthesia.

After surgery, patients' condition was monitored and in the event of any serious post-operative problem operating surgeon usually attended the patients and/or arrangements were made to send the patients to the hospitals with better facilities.

\section{Results:}

Table-I shows the surgical resources available at SHMH. Four general surgeons and four anesthesiologists provided services during the study period. Two full-time experienced medical officers were giving 24 hours service. One qualified operation theatre (OT) nurse and two supporting OT staffs were available. Total bed number in the hospital was 14 .

Table-I: Resources available at the hospital

\begin{tabular}{|l|c|}
\hline Resources & Number \\
\hline Visiting consultants & 04 \\
\hline $\begin{array}{l}\text { Visiting } \\
\text { anaesthesiologists }\end{array}$ & 04 \\
\hline Medical officers & 02 \\
\hline OT nurse & 01 \\
\hline Supporting OT staff & 02 \\
\hline Ward nurse & 01 \\
\hline Operation theater & 02 \\
\hline Bed/Cabin & 14 \\
\hline OT session & Twice a month \\
\hline Pulse oximeter & 01 \\
\hline
\end{tabular}

Table-II shows the trend of patients seen and operated each year. Highest number of patients (840) were seen during July 2004 June 2005. The rate of increase in number of outpatient was $25 \%$ during July 2003 - June 2004. Number of out patients was less (820) during July 2005 - June 2006, a reduction of $2.38 \%$. Highest number (155) of operations were done during July 2004 - June 2005 and highest increase in rate of operation $(64.77 \%)$ was during July 2003 - June 2004 . Number of operation went down by $11.61 \%$ during July 2005 - June 2006 . Total 3,431 patients were seen in the outpatient and 613 operations were performed during the study period.

Table-II: Patients seen and operated by surgical consultants

\begin{tabular}{|l|c|c|c|c|}
\hline \multicolumn{1}{|c|}{ Year } & $\begin{array}{c}\text { No. of } \\
\text { patients } \\
\text { seen }\end{array}$ & $\begin{array}{c}\text { Growth } \\
\text { each } \\
\text { year }\end{array}$ & $\begin{array}{c}\text { No. of } \\
\text { patient } \\
\text { operated }\end{array}$ & $\begin{array}{c}\text { Growth } \\
\text { each year }\end{array}$ \\
\hline $\begin{array}{l}\text { July 2001 to June } \\
2002\left(1^{\text {* }} \text { Yeas) }\right.\end{array}$ & 475 & & 88 & \\
\hline $\begin{array}{l}\text { July 2002 to Junc } \\
2003\left(2^{\text {thl }} \text { year) }\right.\end{array}$ & 576 & $21.26 \%$ & 88 & $0 \%$ \\
\hline $\begin{array}{l}\text { July } 2003 \text { to June } \\
2004\left(3^{\text {rh }} \text { year) }\right.\end{array}$ & 720 & $25.00 \%$ & 145 & $64.77 \%$ \\
\hline $\begin{array}{l}\text { July } 2004 \text { to June } \\
2005\left(4^{\text {th }} \text { year) }\right.\end{array}$ & 840 & $16.67 \%$ & 155 & $6.90 \%$ \\
\hline $\begin{array}{l}\text { July 2005 to June } \\
2006\end{array}$ & 820 & $-2.38 \%$ & 137 & $-11.61 \%$ \\
\hline \multicolumn{1}{|c|}{ Total } & 3431 & & 61.3 & \\
\hline
\end{tabular}


Table-III shows the type of operations done. Most common operation was open cholecystectomy $(42.41 \%, 260 / 613)$. It was followed by herniorrhaphy $(13.70 \%, 84 / 613)$, excision of benign skin and subcutaneous lesions $(13.38 \%, 82 / 613)$ and appendicectomy $(12.23 \%, 75 / 613)$. Few high-risk operations like right hemicolectomy (1), Billroth II partial gastrectomy (2), hemithyroidectomy (I) and open cholcystectomy with cholecdocholithotomy were also done. Most of the surgeries were elective $(85.48 \%$. $524 / 613)$. General anaesthesia was given in $51.88 \%$ (318/613) cases (Fig.-1).

Table-III: Operations done during the study period $(\mathrm{N}=613)$.

\begin{tabular}{|l|c|c|}
\hline \multicolumn{1}{|c|}{ Operation } & Number & $\begin{array}{c}\text { Percentage } \\
(\%)\end{array}$ \\
\hline Open cholecystectomy & 260 & 42.41 \\
\hline Herniorrahphy/Herniotomy & 84 & 13.70 \\
\hline Appendicectomy & 75 & 12.23 \\
\hline Excision biopsyof breast lump & 22 & 3.58 \\
\hline $\begin{array}{l}\text { Excison biopsy of benign skin } \\
\text { and subculaneous lesion }\end{array}$ & 82 & 13.38 \\
\hline Circumcission & 18 & 2.94 \\
\hline $\begin{array}{l}\text { Excision and eversion of } \\
\text { liydrocoele sac }\end{array}$ & 09 & 1.47 \\
\hline $\begin{array}{l}\text { Incision and drainage of } \\
\text { abscess }\end{array}$ & 15 & 2.45 \\
\hline $\begin{array}{l}\text { Vagotomy and } \\
\text { gastrojejunostomy }\end{array}$ & 08 & 1.31 \\
\hline Haemorrhoidectomy & 13 & 2.12 \\
\hline Left lateral sphincterotomy & 08 & 1.31 \\
\hline Fistulectomy & 03 & 0.49 \\
\hline Nephrolithotomy & 03 & 0.49 \\
\hline Others & 13 & 2.12 \\
\hline
\end{tabular}

\footnotetext{
'Rectal polypectomy (2), right hemicolctromy (1). Billroth II partial gasırectomy (2). lumber sympathetectomy (2), excision of pilonidal sinus (1), right hemithyroidectomy (1). orchidectomy (1), colostomy (1), open cholecystectomy with cholcdocholithotomy (2).
}

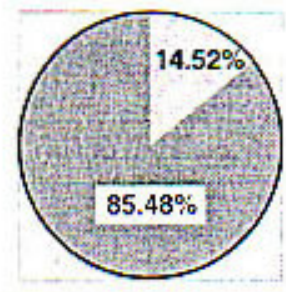

口Emergency (89:613\} 口Elective \{524/613)

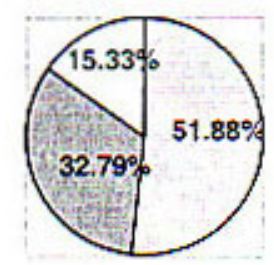

口 G/A (318/613) D Spinal (201/613) D Local (94/613)

Fig. -1: Emergency and elective surgery and type of anaesthesia required $(\mathrm{N}=613)$.

Comparison of cost of three common operations in three categories of hospital settings is presented in Table-V. Complications of three common operations like open cholecystectomy, herniorrhaphy and appendicectomy are presented in Table-IV.

Table - IV: Complications and mortality after three common operations

\begin{tabular}{|c|c|c|c|c|}
\hline & Over all & \begin{tabular}{|c|} 
Cholecystec \\
tomy
\end{tabular} & \begin{tabular}{|c|} 
Ierniorr \\
-alıphy
\end{tabular} & $\begin{array}{l}\text { Appendices } \\
\text { tomy }\end{array}$ \\
\hline $\begin{array}{l}\text { Number of } \\
\text { opsrationin? }\end{array}$ & & 260 & 84 & 75 \\
\hline \multicolumn{5}{|l|}{ Mlusbidity } \\
\hline \begin{tabular}{|l|} 
Surgical site \\
infection (SSI)
\end{tabular} & $\begin{array}{l}263 y \\
(11 / 419)\end{array}$ & $05(1.92 \%)$ & \begin{tabular}{|c|}
02 \\
$(238 \%)$
\end{tabular} & $04(5.33 x)$ \\
\hline Incisional hemia & & $0 \mathrm{t}\left(0.38^{r}\right)$ & - & - \\
\hline Bile duel sajury' & & $01\{0.38 \%\}$ & . & $\cdot$ \\
\hline Bile duc1 vtictete" & & $01\langle 0.38 \%$ & - & $\cdot$ \\
\hline \begin{tabular}{|l|} 
Reactionary \\
hale:moratage'
\end{tabular} & & $01(0.38 \%)$ & & $\cdot$ \\
\hline Scrotal haernatoma & & - & \begin{tabular}{|c|}
02 \\
$(2385)$ \\
\end{tabular} & . \\
\hline Testicular atropsy & & - & \begin{tabular}{|c|}
111 \\
$\left(1.19^{\prime} z\right)$ \\
\end{tabular} & - \\
\hline Testicuiar swelling & & $\cdot$ & \begin{tabular}{|c|}
01 \\
$(1.19 \%)$ \\
\end{tabular} & $\cdot$ \\
\hline
\end{tabular}




\begin{tabular}{|c|c|c|c|c|}
\hline & Over all & $\begin{array}{c}\text { Cholecystec } \\
\text { tomy }\end{array}$ & $\begin{array}{c}\text { Ilerniour } \\
\text {-ahphy }\end{array}$ & $\begin{array}{c}\text { Appendicec } \\
\text { tomy }\end{array}$ \\
\hline Recurrat heraia & &. & $\begin{array}{c}01 \\
\left(1.199_{7}\right) \\
\end{array}$ & - \\
\hline Crronic froin pain & & $\cdot$ & $\begin{array}{c}02 \\
\left(1.19 \sigma_{1}\right) \\
\end{array}$ & - \\
\hline Chest isfoctuva & & $01(0.35 \%)$ & - & - \\
\hline Ileux & & $\cdot$ & $\cdot$ & $01(1.33 \%)$ \\
\hline Distharging sinus & & $\cdot$ & $\cdot$ & $02\{2.675\}$ \\
\hline Total & $\begin{array}{l}6.21 \% \\
(26 \% 419\end{array}$ & $10(3.85 \%)$ & $\begin{array}{c}09 \\
(10.71 \%)\end{array}$ & $07(9.33 \%)$ \\
\hline Mortality & 00 & 00 & $\infty 0$ & 00 \\
\hline $\begin{array}{l}\text { Recognized } \\
\text { hepaticojejun } \\
\text { Reopervted an }\end{array}$ & $\begin{array}{l}\text { during } \\
\text { ostomy. } \\
\text { ad trexted t }\end{array}$ & operation & and & treated \\
\hline Due to clottin & g disord & eeded re & . & \\
\hline
\end{tabular}

\section{Discussion:}

There was an increasing trend in number of patients seen and operated each subsequent year except the last year in SHMH. It was because some Friday consultations could not be made available during the later period due to unavoidable circumstances. Analysis of type of operations showed that cholecystectomy topped the list followed by herniorrhaphy and appendicectomy. Surprisingly, rectal cases were less in number. It may be assumed that food habit of rural people plays an important role in reduced incidence of piles and fissures.

Emergency surgery was too less in number in this study as compared to elective cases due to unavailability of emergency services in the hospital. This charitable hospital is passing through its initial phase and regular emergency services could not be made available for obvious reasons. For this reason and as there was one operation day weekly, minor surgical emergencies like abscess was significantly less in number compared to an audit in a Thana Health Complex where abscess topped the list'. A reasonable number of cases did not need general anaesthesia $(48.12 \%)$ as operations like hemionhaphy and appendicectomy were done under spinal anaesthesia. Overall skin and soft tissue infection (SSI) rate was $2.63 \%(11 / 419)$ in three common operations. The finding is comparable to other international studies. In fact. it is rather low in comparison to some international studies where it ranges from $5.54 \%$ to $26.7 \%^{2,3,4,5,6.7}$. The overall complication rate in common operations was $6.21 \%$. Skin and soft tissue infection in open cholecystecomy was $1.92 \%$ which is quite low when compared to the study of Indigo et al'. They have found an infection rate of $30.9 \%$ in hepatopancreaticobiliary surgery. Skin and soft tissue infection rate in hernia in this series was $2.38 \%$ which was relatively higher in comparison to the study done by Hiersemann et $a f^{5}$ who found a rate only $0.5 \%$ in such cases. However, SSI was found in $5.33 \%$ cases of appendicectomy. a finding significantly better than those of other studies where it ranges from $9.17 \%$ to $15.9 \%^{2.3 .4}$. In this study, infection rate was less. probably because the operations were done and OT was used once a week and proper aseptic precautions were maintained. As OT was used only once a week, so chances of contamination was less. Two biliary complications occurred. One happened peroperatively and corrected by hepaticojejunostomy, and another presented late postoperatively with features of biliary stricture which was also dealt with by hepaticojejunostomy. The biliary injury rate was $0.77 \%$ which was a little higher in comparison to Roslyn et $a l^{8}$ and Strasberg et $a l^{9}$ who reported $0.2 \%$ and $0.3 \%$ respectively. The important thing was that those complications were managed successfully. There was no mortality in this series. Absence of mortality was probably because of 
appropriate selection of patients, efficient surgical and anaesthesiological intervention and very effective post-operative care.

In Table-V, one can find approximately the difference of cost in common operations in different hospital settings, which suggest how a charitable rural hospital can offer services to rural people complimenting the public facilities. It has to be appreciated that to have low cost services in public facilities it involves many unavoidable limitations including waiting time which is not there in the private charitable hospital where serving the humanity better is the motto.

Surgical care can be given satisfactorily in rural settings with satisfactory results provided appropriate setup and relevant expertise can be made available, and then only the benefit would go to the vast majority of poor people in the rural areas. Therefore, low cost private health facilities in rural areas along with public facilities may serve a huge number of rural people who otherwise would be deprived of minimum health care.

\section{References:}

1. Sheikh SH. Surgical audit of 50 bedded hospital, Tongi: 3 years experience. Joumal of Surgical Sciences 2001: 5: 18-20.

2. Inigo JJ, Bermejo B, Oronoz B, et al. Surgical site infection in general surgery: 5-year analysis and assessment of the National Nosocomial Infection Surveillance (NNIS) index. Cir Esp 2006; 79: 224-30.
3. Chattopadhyay R, Zaroukian S, Potvin E. Surgical site infection rates at the Pontiac Health Care Centre. a rural community hospital. Can J Rural Med 2006: 11: 41-8.

4. Hernandez K. Ramos E. Seas C. et al. Tropical "Alexander von Humboldt." Universidad Peruana Cayetano Heredia. Lima. Peru. Infect Control Hosp Epidemiol 2005: 26: 473-7.

5. Hirsemann S, Sohr D. Gastmeier K. et al. Risk factors for surgical site infections in a free- standing outpatient setting. Am J Infect Control 2005; 33: 6-10.

6. Nguyen D. MacLeod WB. Phung DC. et al. Incidence and predictors of surgicalsite infections in Vietnam. Infect Control Hosp Epidemiol 2001: 22: 485-92.

7. Soleto L. Pirard M. Boelaert M. et al. Incidence of surgical-site infections and the validity of the National Nosocomial Infections Surveillance System risk index in a general surgical ward in Santa Cruz. Bolivia. Infect Control Hosp Epidemiol 2003; 24: 26-30.

8. Roslyn JJ, Pinns GS. Hughes EF. et al. Open cholecystectomy: a contemporary analysis of 42.474 patients. Ann Surg 1993; 218: 129-137.

9. Strasberg SM, Hert M. Soper NJ. An analysis of the problem of biliary injury during laparoscopic cholecystectomy. J Am Coll Surg 1995; 180: 101-125. 